\title{
Linguistic Diversity and National Unity: Sustainable Demographic Development of Multi-Ethnic Population in Russia
}

\author{
Yagfar Zakirovich Garipov, Dr., Prof.
}

Kazan (Volga Region) Federal University tatgarip@yandex.ru

\section{Marina Ivanovna Solnyshkina, Dr., Prof.}

Kazan (Volga Region) Federal University mesoln@yandex.ru

\section{Doi:10.5901/mjss.2015.v6n1s1p540}

\section{Abstract}

The article exemplifies controversial features in the linguistic development of the multiethnic population of Russia in the Volga Federal District, predominantly in the Republic of Tatarstan1; it analyzes the roles titular and official languages of the Russian Federation play in different spheres of life. The surveys held in Tatarstan over the last decade prove that enthusiasm of the ethnic 'Renaissance' of late 1990s has been changed by a disappointing estimation of Tatar still playing the role of a means of communication for a limited ethnic community, not viewed by the ethic population as one of the main elements of their ethnic identity. There is evidence that failure to ensure the revival and intergenerational transmission of the Tatar language (one of the most developed in the Volga Federal Region and Russia) may accelerate negative demographic shifts and further reduction of the ethnic language functions. The authors consider the present situation in Tatarstan to be caused by the lack of language policy coordination on three levels: federal, local and individual (family). It is suggested that to ensure the ethnic and language reproduction in a federal state, language regulations initiatives are to be based on the concept of the languages being 'inherent property' of an ethnos, the most important qualitative characteristic of a state of the ethnos, and essential grounds for its existence and development. Sustainable ethno-linguistic reproduction and native languages preservation are viewed by the authors possible due to implementation of the idea of linguistic federalism and development of ethnic linguistic identity.

Keywords: language development, identity, policy, linguistic federalism, sustainable development.

\section{Introduction}

One of the central goals of the Soviet Union policy was forming a united single 'Soviet narod' (people) which, Lenin believed, would be formed by natural coalescing of all the ethnic groups residing on the territory of the Soviet Union (Language Policy in the Soviet Union). In 1918 M.M. Sahyanova, a leader of Buryat ${ }^{2}$ Bolsheviks declared that communists as a revolutionary party of workers were not divided by their belonging to different ethnic groups, and an ethnos was not considered a value by Bolsheviks. (National Movement..., 1994, p. 122). 68 years later, in 1983 the leader of the USSR, General Secretary of the Central Committee of the Communist Party, Y.V.Andropov echoed his Communist fellow declaring: "Our goal is obvious. It is, by Lenin, 'not only convergence of ethnic groups, but their merger"' (Andropov, 1983, p. 117). Thus, the Communist way of uniting people into 'Sovetskiy narod' did not imply maintaining czarist Russia ethnic diversity, but was supposed to lie through multi-stage ethnic assimilation, when an ethnos acquires attributes of another and dissolves in it.

Fluctuations of the language policy in the Soviet Union - from investments in developing indigenous languages to Russification - resulted in that unique early 1990-s situation when absolutely all former Soviet Republics were eager to begin and did begin their native languages revivals.

The present situation, about a quarter of a century after the first Language programs were developed in different post-Soviet Republics, is apparently complex. On the one hand there is a manifested growth of titular population in a

${ }^{1}$ The Tatars are the second largest ethnos in the Russian Federation after the Russians (111,02 m/n., 80,90\%) numbering 5,31 mln (3,87\%) (All Russia Census, 2010).

${ }^{2}$ The Buryats numbering approximately 500,000, are the largest indigenous (aboriginal) group in Siberia, mainly concentrated in their homeland, the Buryat Republic, a federal subject of Russia (All Russia Census, 2010). 
number of regions and educational establishments providing titular languages teaching, but on the other hand, "nonRussian peoples are affected by progressive language loss, in particular among younger generations" (Zamyatin 2012). Addressing the problem, the authors view linguistic federalism and development of ethnic linguistic identity as the main instruments to increase the role and significance of the indigenous languages and provide for sustainable development of an ethnos. Preservation of ethnic diversity in a multi-ethnic country becomes a reality when the shared by different communities view on the ethnic language as the most significant component of the ethnic identity and as such is favored and empowered by the federal and regional legislation on national and language issues.

\section{Hypotheses}

The major study hypotheses is as follows: Tatarstan language policy, though having made large investments into the Tatar language provision, failed to develop in Tatars the view on the language as a unique socio-cultural value, as the main component of ethnic identity.

\section{The Research Objective and Methods}

The study objectives are as follows: 1) to outline the trends that show varying dynamics in language estimation and Tatar language functions in the republic of Tatarstan during the period from early 1990-s to 2013; 2) to demonstrate how the Soviet legacy predetermined the current situation in the Russian Federation, 3) to understand the reasons behind the current language situation in the Republic of Tatarstan, and 4) to explain the Tatar language intergenerational transmission failure.

The authors predominantly applied a comparative analysis of the data registered by official sources as well as expert evaluations of the demographic and socio-cultural situation in the country, which combined provide evidence for the success and failings inherent in pursuing the language policies in Tatarstan within the last twenty years.

The additional methods applied in the research are group-administered and mail surveys in which respondents were provided either with a short paper-and-pencil or electronic feedback forms with the request to answer closed-ended questions. Aimed at collecting samples generalizable to the total population of the Republic of Tatarstan, the surveys were used to learn directly from the population about their beliefs, values, feelings, and motivations that underlie behaviors, and to provide the context necessary to understand the data registered by official sources (Census) as well as expert evaluations of the demographic findings, and to identify the current language situation in the Republic.

\section{Literature Review. Common Language.}

\subsection{Ethnos.}

N. Gumilev defines an "ethnos" as a group of people who oppose themselves to all other such-like groups on the basis of their unconscious feeling of mutual relatedness and togetherness which leads to the opposition of "us" to "them" (Gumilev 1992, 10). Different ehne differ in culture, language and religion (Idrisova 2007).

\subsection{Language and Socialization.}

The language is considered by the authors as an 'inherent property' of an ethnos, one of the most important qualitative characteristic of the state of an ethnos, and essential grounds for an ethnos existence and its development. But "an ethnic identity is not an innate human characteristic" (Gellner, 1991, p. 34): values, interests, personality traits and behavioral stereotypes are formed in socialization. A Tatar, or a Yakut, is unlikely to be raised in a family of Russian parents where communication is conducted in Russian. Cultural and language socialization does not directly affect the birth rate; however it certainly impacts upon a child's attribution to a particular ethnic community. The Russian philosopher Ivan llyin emphasized the importance of three factors in ethnic (Russian) socialization: the child must "start talking and try to express himself in his native language, hear a Russian song in the cradle, and obtain a source of spiritual power, the Russian power through prayer" (Ilyin 1992).

Culture has never been and will never be abstract, it is always concrete, human, i.e. ethnic (Berdyaev 1990 p. 85). "Any ethnic culture is based primarily on the language, and ethnic identity implies an excellent command of the language. Thus, the Russian language is viewed as the absolute foundation of Russian culture, and Russianness, and the most important tool of the individual socialization within Russian cultural tradition" ( Zdravomyslov 2001, p. 44). Though any 
culture is ethnic and its unique character is reflected in the language, the functional relationships between culture and language are not so straightforward and obvious. "Feeling their belonging to a particular culture, people do not always realize that its fundamental conceptual values are expressed in its linguistic forms. It is the language interaction that serves as the environment for mutual understanding of individuals, nations and states" (Aitmatov 1998, p. 30).

\subsection{Indigenous People.}

The term 'indigenous people' is used in the article to refer to those groups specially protected in specified international or national legislation as having a set of specific rights based on their historical ties to a particular territory, and their cultural or historical distinctiveness from other populations (Coates 2004).

\subsection{Ethnic Assimilation.}

In any multi-ethnic country with a significant quantitative or socio-cultural superiority of one of the contacting ethnic groups assimilation is inevitable. However, the desire to 'push' these processes is wrong and unacceptable, as well as the desire to stop them completely. "No nation in the world, especially the people forming a state, would voluntarily allow the destruction of their national physiognomy in the name of assimilation, even with a more advanced ethnos" (Trubetskoy 1995 p. 63-64). Thus, effective national policy involves consideration and implementation of ethnic dimensions of socio-demographic processes.

The nation's language transformation in socio-economic development and state language policy determine many of the ethno-demographic processes, the reproductive potential of an ethnos, the number of contacting ethnic groups in separate republics (regions) and the country as a whole. In this perspective, we strongly oppose the recommendation to confront "the view on the loss of, or rather a change of the language results in the loss of ethnic identity and the disappearance of a separate ethnos" (Tishkov 2001, p. 219).

The process of assimilation, or ethnic de-generation, 'dissolution' in the quantitatively or socially imposing ethnic environment is an essential factor of demographic troubles for indigenous (titular) population in the republics of Russia. Limiting the scope of an ethnic language followed by its complete withdrawal from circulation, serves as an important factor in assimilation, manifesting itself in the process when a community belonging to an already formed ethnos adopts the language, culture and customs of another ethnos with whom the community contacts and shares the environment. The succeeding generations of the community do not identify themselves as belonging to their ethnos of their forefathers.

Assimilation can also be caused by inter-ethnic (mixed) marriages (Demographic conceptual dictionary, 2003, p. 12-13). "It is not only the birth rate decline that affects the documented rate of the non-Russian peoples reproduction, but also parents' arbitrary decision on the child's ethnicity" (Zakiev, p. 38).

\section{Studying the Question}

\subsection{Demographic Processes in Modern Russia.}

The Atlas of Endangered Languages, published by UNESCO indicates that 136 languages of the Russian Federation are under the threat of extinction (Uhtin 2010), the main reasons of which include assimilation into a stronger ethnos or migrations.

\subsubsection{Assimilation.}

Forecasting the demographic climate in Russia V.A Tishkov wrote: "The extension of the concept of Russianness and assimilation in favor of Russian, existing in the country for centuries, will be the main compensatory mechanisms of relatively low birth rates among culturally dominant ethnic group of Russia" (Tishkov 2001, p. 219). Studying the findings of the National Population Census conducted in 1959 and identifying 108 language groups, a prominent RussianAmerican sociologist Sorokin noted: "many of the non-Russian ethne have been 'russified' and assimilated: the National Population Census of 1959 showed that people of different ethnic groups (ranging from from 2 to 80\% in different areas) considered Russian as their mother tongue. Consequently, this 'Russified' part of the previously non-Russian ethnic groups can be considered as part of the Russian ethnos" (Sorokin, p. 34).

The similarity of languages sometimes enables to 'increase' the number of one ethnic group at the expense of another: during All-Russia National Census 2002, Tatars, culturally close to Bashkirs, in Bashkortostan were 
acknowledged and registered as Bashkirs, thus outnumbering ethnic Russians in Bashkortostan and providing the Republican elite with provilages (Zamyatin 2012, p. 80).

The opposite process - the shift back in self-identification - took place in modern Mordovia where "the growth of the proportion of ethnic Mordvins from 31.9\% up to 40\% between the 2002 and 2010 censuses ... should be attributed to the trend that those individuals of Mordvin descent who, in previous censuses, declared themselves to be Russians changed back to declaring themselves as Mordvins as a result of encouraging regional policy and following positive changes in popular attitudes towards the titular ethnicity(Zamyatin 2012, p. 79).

\subsubsection{Migration.}

The effect of the language development of population on migration is obvious and does not cause any doubt among researchers. Even in Soviet times, the prevalence of interethnic communication (Russian) language was considered as a significant factor in increasing the migratory activity of indigenous labor surplus Asian republics, and considerable efforts for its intensification were taken. The radical social, political, economic transformation, the collapse of the Soviet Union and the formation of new independent states, which led to a change of the Russian language status in these republics, largely caused the immigration of Russian and Russian-speaking population to the Russian Federation.

\subsection{Volga Federal District}

Six out of the 21 republics of the Russian Federation, Bashkortostan, Mari El, Mordovia, Tatarstan, the Udmurt Republic and Chuvash Republic are located in the Volga Federal District. The percentage of indigenous people in these republics ranges from 29.3\% (Udmurt Republic) to 67.8\% (Chuvashia) (Russian Census, 2010).

The findings of the All-Russia Census (2010) also indicate that $74.7 \%$ of Bashkirs, $78.5 \%$ of Mari, $84.6 \%$ of Mordovians, $94.2 \%$ of Tatars, $71.8 \%$ of Udmurt, $85.8 \%$ of Chuvash speak their native languages.

In late 1980-s and early 1990-s all Republics of the Russian Federation received the right to conduct extensive independent language policy. Most of them ordained Laws on Languages (see the Law of the Republic of Tatarstan, 1996) and began a long process of widening the range of spheres where the titular languages were functioning. Tremendous efforts of the titular peoples of the republics were aimed at revitalization, revival of the functions of native languages. ('Data, 1991-2004; 'Data, 2004-07; Gataullina, 2001).

\subsubsection{Volga Federal District: The Role of The Russian Language. Contemporary State of Affairs.}

Migration has changed the share of Russian and Russian speaking people in many republics of the Russian Federation. The roles of different languages in cultural, social and political life of the Russian society have greatly transformed, but in all the Republics of the Russian Federation the Russian language retains its dominant position, being the language of governing bodies, education, means of intra-national communication and media. According to the All-Russia Population Census (Russian Census, 2002), 93\% of the Bashkirs, $97 \%$ of Mari, $98.7 \%$ of Mordovians, $92.9 \%$ of Tatars, $98.4 \%$ of Udmurt, $95.6 \%$ of Chuvash speak and use the Russian language in everyday communication.

\subsubsection{Tatarstan: The Language Policy. Indigenous languages.}

All-Russia Population Census (Russian Census, 2002) demonstrated that over 140 ethne make the population of Tatarstan, although the overwhelming majority are Tatars (52.9\%) and Russians (39.5\%).

The proclamation of Tatar as one of the official languages of the Republic of Tatarstan (with Russian being the second) was followed by a number of actions: Law "On Languages of the Republic of Tatarstan" ( 1996), the "State Program On Preservation, Study and Development of the Official Languages Of The Republic Of Tatarstan and Other Languages in the Republic Of Tatarstan" for 1994-2003, 2004-2013, 2014-2020.

According to the information provided by the Ministry of Education and Science of Tatarstan (2009), 1061 Tatar and 888 Russian schools functioned in the Republic. 100\% of Russian children and $48.4 \%$ of Tatar children are taught in their native language. There are 32 grammar schools (gymnasia) focusing on Russian ethno-cultural component in Tatarstan, the Republic is implementing the federal program "The Russian Language"(2011 - 2015).

The indigenous language is the media of instruction in 120 Chuvash schools (7392 pupils), 21 Mari (850), 5 Mordovia (103), 41 Udmurt (1086), one Bashkir (12), one Jewish school (221). There are 44 Sunday schools in the national-cultural autonomies where 28 languages of nations living in the republic are studied. 
According to the 2002 National Population Census (Russian Census, 2002), 86.5\% of Chuvash in Tatarstan speak their native language, whereas the number of people speaking native language in Chuvash republic records $85.8 \%$. $87.4 \%$, of Udmurts in Tatarstan speak their mother tongue while in their country the number counts for only $71.8 \%$. The corresponding figures for Mari are $74.5 \%$ and $78.5 \%$ respectively, for Mordovians are $79 \%$ and $84.6 \%$ respectively. The first secondary school with Udmurt medium language was founded in Tatarstan, not the Udmurt Republic (Russian Census, 2002).

\subsubsection{Tatarstan: The Language Policy. The Tatar Language.}

Tatarstan is home to only $36 \%$ of Tatars of all Russian Tatars. According to the National Population Census of $200273 \%$ of Tatars in Russia speak their native language.

In early 1990-s Tatarstan invested a lot in widening the domain of the Tatar language functioning both in and outside the Republic. Realizing the Law on Languages (1996), Tatarstan Parliament (State Council) worked out and adopted "State Programme of the Republic of Tatarstan on Preservation, Improvement, Studies and Development of the Peoples of the Republic of Tatarstan" (1994), the Government of the Republic established the Committee on Realization the Law of the Republic of Tatarstan "On Languages of Peoples of the Republic of Tatarstan" (1996) and seven public commissions in charge of functional extension of the Tatar language ( e.g. Codification and Language standards in different areas, Tatar in Information Technologies etc.). Issues of the Tatar language provision in every school of the Republic were supervised by a specially appointed Principal deputy accountable to the corresponding district Educational Department. Every district of the Republic of Tatarstan worked out and realized its own programme on the language development, districts administrations ( including the capital - the city of Kazan) set up Departments on Ethnic Affairs and Funds of languages and cultures development of all the peoples living on the territory.

In 1990s, when language reforms were in full swing many enthusiasts viewed the Tatar language teaching as a lever to form, develop and increase positive ethnic self-identification of Tatars (Garipov 2003), which as a positive reflection of one's belonging to an ethno-linguistic community implies willingness to socialize with people of the same ethnos, preserve and develop the native language and aim at ethnolinguistic reproduction of the ethnos. But the reality showed that language proficiency does not imply high ethnic identification. Local researchers assess the results of language policy implementation as moderate: "the language shift in Tatarstan is suspended but not reversed" (Musina 2011, 27).

Some positive changes for the better awareness of ethnic identification of Tatars are also registered: "Today young Tatars in their Internet interactions within social communities demonstrate a strong and marked self-awareness of their ethnic identity, they freely and openly self-present and promote their Tatar ethnicity" (Bashirova et all, 2014).

However, All-Russia National Population Census (2010) evidentiated that 166000 (19.2\%) out of 5.5 million Russian Tatars, do not know their ethnic mother tongue. "We should not deceive ourselves that the so-called Russianspeaking community of Tatars is being formed. There has never been and will never be such ethnic group. This is a transition community from ethnic Tatars to Russians. The person, who lost his/her native language in the first generation, in the second generation loses his/her ethnic mentality, and in the third generation completely becomes a Russian of Tatar origin", writes N.M Mirihanov (2006). Losing the language, a person loses the national spirit, national image and becomes a representative of the ethnos whose language he/she adopted.

If the present tendency continues, the modern Tatar ethnos has all the chances to obtain the status which can be described with a paraphrase of a famous Russian classic: "Scratch a Tatar, and you will find a Russian"3.

\section{Analyses: Progressive Loss of Ethnic Identity}

To confirm or contradict the hypotheses of the research and the findings of other researchers on the same issues, three different surveys were conducted by the authors in 2001 (Survey 1), 2005 (Survey 2), 2013 (Survey 3).

\subsection{Survey 1.}

According to the group-administered survey conducted by the authors in (2001), $69 \%$ of 467 Tatars would like their children (or grandchildren) to be educated in the traditions of ethnic culture. However, more than half of them (53.8\%) would like their children to be educated in Russian-speaking schools where the Tatar language is studied only as a

${ }^{3}$ Karamsin's popular aphorism says "Scratch a Russian and you will find a Tatar". 
subject. In 1996 the figures were not significantly different: 68\% and 53\% respectively.

Due to the fact that Tatar-medium schooling is not provided at the stage of vocational and tertiary education, Tatar parents consider Tatar-medium schools to be unpromising and dead-end. Moreover the survey showed that some parents (about 4\%) consider that primary Tatar-medium schooling is to result in significant difficulties at higher education levels and make Tatar school graduates less competitive at labor market.

\subsection{Survey 2.}

Survey 2 (2005) was aimed at evaluating the importance of the native language for the young in the oil districts of the republic (Aznakaevo, Bugulma, Nabereznye Chelny). While asked the question "What function does your native language play in your life?" $31 \%$ of 245 Tatars and $59.5 \%$ of 257 Russian respondents defined it as a means of communication. $15 \%$ of the Tatar and $16.5 \%$ of Russian respondents claimed that "knowing and being able to speak their mother tongue" is a guarantee of their ethnic community existence.

\subsection{Survey 3.}

The population selected for Mail Survey 3 (2013) were 78 academicians of Tatartsan educational establishments with doctoral degrees. While replying the closed-ended question on the role of the native language, $32.7 \%$ of Tatars and $51.4 \%$ of Russians selected 'means of communication'. And only $28 \%$ of Tatars and $8.6 \%$ Russians view the native language as a decisive factor of their ethnic identity survival.

The fact that Russians gave low estimates of the importance of native language can be explained by the much broader functional domain of the Russian language and its main role in all social spheres on the territory of the Russian Federation.

As for the low percentage in answers of Tatars, they indicate the lack of reflection on the role of indigenous languages in general and Tatar in particular in preserving the ethnos. They also point to underestimating the severity of the problem.

\subsection{Intergenerational Language Transmission}

Raising children implies ethnic socialization. This idea was vividly expressed by Sergei Mironov, the Chairman of the Federation Council, Russia, in one of the TV broadcasts, dedicated to the demographic problems of Russia: "I want my children and grandchildren to be Russian" (of Channel 1, "Times", December 4, 2005).

The significance of ethnic socialization of children is increased if it is accomplished in the presence of a language which offers more power and/or opportunities. In Tatarstan the situation is aggravated by the fact that only half of all those who speak Tatar chose it as the language of everyday life family communication (Census of 2002, 2010). Typically in Tatarstan all types of daily communication start in Russian with very few exceptions when communicators know that their partners speak Tatar.

The authors of the article can boast of a fairly wide circle of friends, including Tatars. But only three of them when picking up a telephone receiver start with "Әйе, тыңлыйм!" (Yie, Tynlyim. Yes, speaking). One of them is an active participant of the national movement, the other is a 90 year-old woman, the third is the Head of the Department of Foreign Languages of one of the universities in Naberezhnye Chelny.

Thus, the surveys and the analyses confirm the hypothesis of the research: Tatar is used in daily life and cultural sphere by a limited population and as such is viewed as a means of communication only, not the cornerstone of the ethnic identity.

\section{Conclusion}

Huge efforts have been taken in Tatarstan to implement a wide variety of language development programs, as a result, nowadays Tatarstan citizens have the right and possibility to choose the language of education and training. But limited power and/or opportunities of Tatar and deficiencies in the Tatar language teaching lead to the lack of intergenerational language transmission within families. The causes of the present day situation in Tatarstan lie in federal national policy and republican language legislation defining the language as a means of communication not as a main socio-cultural ethnic value and an indispensable requirement of the ethnos survival.

The authors consider that complete functional 'recovery' of indigenous languages and their utilization in all spheres 
can be achieved by a number of measures on all levels: federal, local and individual (family). The concept of polyethnicity is viewed by the authors as a way to exclude language assimilation, ensure cultural development of every ethnos and preserve historical perspectives of a nation. But to confirm or overrule the idea, more extensive studies are required.

\section{References}

Aitmatov Ch. (1998) National and Global in Culture. The Unity and Diversity of Cultures (Nacionalnoe i globalnoe v kulture. Edinstvo i raznoobrazie kultur). European Integration. Humanistic Europe and Culture. - M.: USSS, 1998.

Andropov, Yu.V. (1983). Sixty years of the USSR. XXVI Congress of the CPSU: The Unity Of Theory And Practice (Shestdesyat let SSSR. XXVI sezd KPSS: edinstvo teorii i praktiki). Moscow: Politizdat, 1983. Vol. 3.

Bashirova, N.Z. \& Solnyshkina, M.I. (2015). Representation of Ethnic Identity Of Tatars Through The Ethnonym 'Tatar', Cambridge: Cambridge Scholars Publishing (in press).

Berdyaev, N. A. (1990). Destiny of Russia. (Sudba Rossii. Sbornik statej (1914 - 1917)) Moscow: Mysl.

Coates, Ken S. (2004). A Global History of Indigenous Peoples: Struggle and Survival. New York: Palgrave MacMillan.

Data on Development of National Education in the Republic of Tatarstan 1991-2004' and 'Data on Development of National Education in the Republic of Tatarstan 2004-07'. Republic of Tatarstan Ministry of Education. [Online] Available: http://mon.tatarstan.ru/rus/info .php?id=7141. (October 12, 2012) (In Russian).

Data on Development of National Education in the Republic of Tatarstan 1991-2004' and 'Data on Development of National Education in the Republic of Tatarstan 2004-07'. Republic of Tatarstan Ministry of Education. [Online] Available: http://mon.tatarstan.ru/ rus/info.php?id=7141 (December 5, 2012).

Demographic Conceptual Dictionary. (2003) (Demografichesliy konceptualnyi slovar). Ed. by L.L Rybakovsky. - M.: DSP.(in Russain).

Garipov, Y. \& Faller, H. (2003). The Politics of Language Reform and Bilingualism in Tatarstan. F. Daftary, and F. Grin, (eds.) Nation Building, Ethnicity and Language Politics on Transition Countries. Budapest: LGI/ECMI, pp.163-184.

Gataullina, M. (2001). Vedushchie tendentsii razvitiia tatarskoi natsionalnoi shkoly (1985-2000) (Leading Tendencies in Development of Tatar National School (1985-2000)). Kazan: Pechatnyi Dvor, 2001.

Gellner, E. (1991.) Nations and Nationalism: Trans. from English. / Ed. and afterword. II Krupnik. - Moscow: Progress Publishers.

Government Program of the Republic of Tatarstan on Preservation, Study and Development of the Languages of the Republic of Tatarstan, (1996). (Pravitelstvennaya Programma Respubliki Tatarstan po sohraneniyu, izucheniyu I razvitiyu yazykov Respubliki Tatarstan) Kazan: Tatizdat. 41 p. (in Russian).

Gumilev, L.N. (1992). From the Rus to Russia. Moscow: Ekopros.

Idrisova, Yu.A. (2007). Creating a positive ethnic identity older adolescents: abstract dis. . cand. psychol. sciences. (Formirovanie pozitivnoj etnicheskoj identichnosti starshix podrostkov: avtoreferat dis. . kand. psixol. nauk) Samara:SGU, 25 p.

Ilyin, I.A. (1992). On the National Education. Moscow Journal. - Moscow. № 2. P. 5-7.

Language Policy in the Soviet Union. [Online] Available: www.unc.edu/ lajanda/slav167langpolussrch2.ppt) (November 13, 2014).

Law of the Republic of Tatarstan. On the Languages of Peoples of the Republic of Tatarstan, (1996), (O yazykah narodov respubliki Tatrstan. Zakon Respubliki Tatarstan. [Online] Available: http://www.notatar.narod.ru/tzyaz.html (September 23, 2014).

Ministry of Education and Science of the Republic of Tatarstan. Official website [Online] Available: http://mon.tatarstan.ru/eng/ (November 1, 2014).

Mirihanov, N. M. (2006). The Tatar-Mongols (Tataro-Mongoly). Novosti Tatarstana. 2006. № 11 (148). (In Russian)

Musina, R. et al. (2011). Iazyki v sisteme obrazovaniia Respubliki Tatarstan: po materialam etnosotsiologicheskogo issledovaniia (Languages in the System of Education of the Republic of Tatarstan: Following the Data of an Ethno-sociological Research). Kazan: Tatar Book Publishing House.

National Movement in Buryatia in 1917-1919: Documents and materials, (1994). (Nacionalnoe dvizhenie v Buryatii v 1917-1919: Dokumenty i materialy) / Comp. by B.B. Batuev. Ulan-Ude: ONC "Sibir".

Russian Census. (2002). Osnovnye Itogi Vserossiskoy Perepesi (The Main Results of the All-Russia Census). Moscow: Goskomizdat. 46 p. (in Russian).

Russian Census. (2010), Vserossiskaya Perepes Naseleniya (All-Russia National Population Census). [Online] Available: http://www.gks.ru/free_doc/new_site/perepis2010/croc/perepis_itogi1612.htm. (14 October 2014)(In Russian).

State Program on Preservation, Study and Development of the Official Languages Of The Republic Of Tatarstan and Other Languages in the Republic Of Tatarstan for 2004-2013. (Gosudarstvennaya programma Respubliki Tatarstan po sohraneniyu, izucheniyu i razvitiyu gosudarstvennyx yazykov Respubliki Tatarstan i drugix yazykov v Respublike Tatarstan na 2004 - 2013 gody). [Online] Available: http://prav.tatarstan.ru/complan.htm?pub_id=433. (November 3, 2014).

State Program On Preservation, Study and Development of the Official Languages of the Republic Of Tatarstan and Other Languages in the Republic Of Tatarstan" for 2014-2020. (Postanovlenie Kabineta Ministrov № 794 ot 25.10.2013 "Ob utverzhdenii gosudarstvennoj programmy «Soxranenie, izuchenie i razvitie gosudarstvennyx yazykov Respubliki Tatarstan i drugih yazykov v Respublike Tatarstan na 2014 - 2020 gody) [Online] Available: http://prav.tatarstan.ru/docs/post/post1.htm?pub_id=203458. (November 4, 2014).

State Programme of the Republic of Tatarstan on Preservation, Improvement, Studies and Development of the Peoples of the Republic of Tatarstan. (1994). (Postanovlenie VS N 2186-XII ot 20. 07. 1994 "Ob utverzhdenii gosudarstvennoj programmy RT po 
sohraneniju, izucheniju i razvitiju jazykov narodov RT“). Vedomosti Verhovnogo Soveta Tatarstana. avgust-sentjabr' 1994. № 89. S. 3-18.

The Federal Program "The Russian language", 2011-2015 (Federalnaya celevaya programma "Russkij yazyk" na 2011-2015 gody). [Online] Available: http://mon.tatarstan.ru/fcprus.htm (November 8, 2014).

Tishkov, V. (2001). A Language and Alphabet as a Politics. Ethnology and Politics. Moscow: Nauka.

Trubetskoy, N.S. (1995). History. Culture. Language. (Istoriya. Kultura. Yazyk) M.:Progres.(In Russian).

Uhtin, N.V. (2010). 136 languages can disappear in the Russian Federation (V RF mogut ischeznut 136 yazykov.). Argumenty nedeli. 12.05. 2010. № 18 (208).

Zamyatin, K. (2012). From Language Revival to Language Removal? The Teaching of Titular Languages in the National Republics of Post-Soviet Russia. Journal on Ethnopolitics and Minority Issues in Europe. Vol 11, No 2, 2012, 75-102.

Zdravomyslov, A. (2001). Transformation of Senses in National Discourse (Transformaciya smyslov v nacionalnom diskurse). Yazyk i etnicheskij konflikt. M.: Moskovskij centr Karnegi, Gendalf. 